\title{
METEOR DALAM PERSPEKTIF AL-QUR'AN DAN SAINS
}

\section{METEORS IN THE PERSPECTIVE OF THE AL-QUR'AN AND SCIENCE}

\author{
Muhammad Al Imron ${ }^{1}$, Sodikin $^{2}$, Romlah $^{3}$ \\ ${ }^{1,2}$ Prodi Pendidikan Fisika Fakultas Tarbiyah dan Keguruan Universitas Islam Negeri Raden Intan \\ Lampung \\ ${ }^{3}$ Prodi Pendidikan Guru Raudhatul Athfal Fakultas Tarbiyah dan Keguruan Universitas Islam Negeri \\ Raden Intan Lampung \\ E-mail: muhammadaliimron05@gmail.com
}

Diterima: 5 September 2019. Disetujui: 20 Oktober 2019. Dipublikasikan: 29 November 2019

\begin{abstract}
This study aims to determine the substance of the meteor and the efforts that must be made if the meteor threat actually occurs. This study uses qualitative research type library (Library Research). Researchers as human instruments must have extensive insight to find and determine data sources, both primary and secondary, and then collect these data using reading, documentation and observation techniques. The data analysis technique uses the Milles and Huberman model techniques. Based on the results of the research, it can be found that the substance of the meteor has several benefits, namely as a guardian of the sky, as the forerunner of the existence of water on earth, as the forerunner to the existence of iron on earth, and some disasters on the extinction of dinosaurs and other earth creatures.
\end{abstract}

Keywords: Al-Qur'an, meteor, science

\begin{abstract}
Abstrak:Penelitian ini bertujuan untuk mengetahui substansi dari meteor serta upaya yang harus dilakukan apabila ancaman meteor benar-benar terjadi. Penelitian ini menggunakan penelitian kualitatif jenis pustaka (Library Research).Peneliti sebagai human instrument harus memiliki wawasan yang luas untuk mencari dan menentukan sumber data, baik primer maupun sekunder kemudian mengumpulkan data-data tersebut dengan menggunakan teknik membaca, dokumentasi dan observasi.Teknik analisis data menggunakan teknik model Milles dan Huberman. Berdasarkan hasil penelitian dapat ditemuakan bahwa substansi dari adanya meteor memiliki beberapa manfaat yaitu sebagai penjaga langit, sebagai cikal bakal adanya air di bumi, sebagai cikal bakal adanya besi di bumi, dan beberapa bencanadi bumi yaitu sebagai penyebab punahnya dinosaurus dan makhluk bumi lainnya.
\end{abstract}

(C) 2019 Unit Riset dan Publikasi Ilmiah FTK UIN Raden Intan Lampung

Kata Kunci: Al-Qur'an, meteor, sains

\section{PENDAHULUAN}

Bersamaan dengan kehidupan manusia yang terus berkembang(Yuberti 2018), mereka selalu ingin mencarai tahu mengenai apa yang ada di alam semesta ini, salah satunya adalah fenomena meteor. Meteor merupakan sebuah sebutan untuk suatu penampakan jalur jatuhnya benda-benda langit yang memasuki atmosfer bumi. Setiap tahunya meteor- meteor dan asteroid akan menghujani bumi(Deded Chandra, $\mathrm{M}$. nasir 2016)

Ketika meteor atau asteroid yang masuk ke atmosfer bumi berukuran kecil maka akan menjadi penghias langit yang indah dipandang dan berbagai manfaat lainnya. Namun, ternyata tidak semua meteor atau asteroid dan benda luar angkasa lainya memiliki ukuran kecil, sebagian benda langit itu terkadang memiliki bobot hingga puluhan ton (Thayyarah 2013). 
Ketika benda langit dengan ukuran puluhan ton tersebut menghujani bumi, maka yang akan terjadi adalah bencana besar dan dahsyat yang akan menimpa semua manusia, sebagaimana bencana global 65 juta tahun lalu yang telah mengakhiri 100 juta tahun kekuasaan mahluk-mahluk bumi dinosaurus (Matthews 2015).

Oleh karena itu, meteor merupakan sebuah objek kajian yang menarik bagi peneliti, untuk dikaji dari sudut pandangAl-Qur'an dan sains. Untuk mengungkap bagaimana substansi dari adanya meteor dalam sudut pandang pandangAl-Qur'an dan sains

\section{METODE PENELITIAN}

Penelitian ini menggunakan metode penelitian kualitatif atau yang disebut sebagai penelitian naturalistik, (Sugiyono 2016) dengan jenis penelitian pustaka (library research). Library researchadalah serangkaian kegiatan yang berhubungan dengan metode mengumpulkan data pustaka melalui kegiatan membaca, mencatat dan mengolah data penelitian(Mestika Zed, 2017). Untuk dapat meneliti dan memperoleh data-data yang validdan terjamin keotentikannya, maka digunakan sumber data primer dan sumber data sekunder. Sumber data primer yaitu sumber data yang langsung memberikan data kepada peneliti. Sedangkan sumber data sekunder yaitu sumber data yang tidak langsung memberikan data kepada pengumpul data(Kaelan 2012).

Teknik pengumpulan data yang peneliti gunakan dalam penelitian kepustakaan ini yaitu dengan tekhnik membaca, dokumentasi dan Observasi. Tekhnik analisis data menggunakan model Milles dan Huberman, dengan langkah-langkah sebagai berikut :

1) Reduksi data;

2) Penyajian data/display data;
3) Penarikan kesimpulan/verifikasi

(Iskandar 2013)

HASIL DAN PEMBAHASAN

A. Substansi Meteor Dalam Perspektif Al-Qur'an Dan Sains

1. Asal Usul Meteor Dalam Perspektif

\section{Al-Qur'an Dan Sains}

Fenomena emisi cahaya yang terjadi di dalam atmosfer bumi atau yang biasa disebut sebagai meteor, terjadi akibat benda langit yang jatuh dan bergesekan dengan atmosfer bumi dengan kecepatan 11 sampai $72 \mathrm{~km} /$ detik sehingga terbakar dan menimbulkan pijaran api. Namun tidak dapat diketahui secara pasti, entah dari mana benda langit tersebut berasal. Kemungkinan bisa berasal dari pecahan asteroid, meteoroid, komet atau benda langit lainnya.

Penjelasan sains tersebut seperti yang telah dijelaskan dalam Al-Qur'an surat Al-Mulk ayat 5.

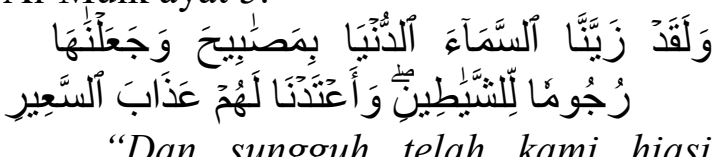

"Dan sungguh telah kami hiasi langit yang dekat, dengan bintangbintang, dan kami jadikannya (bintang-bintang itu) sebagai alat pelempar setan. Dan kami sediakan bagi mereka adzab neraka yang menyala-nyala. (Al-Mulk:5)

Dalam ayat di atas dijelaskan bahwa meteor-meteor yang digunakan untuk melempar setan berasal dari bintangbintang. Sebagaimana yang dijelaskan dalam tafsir Jalalain:

و لقد زيناالسماء) القربي الى الارض ( ) ( )

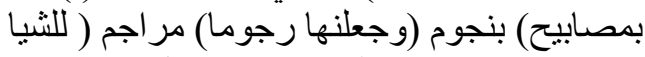

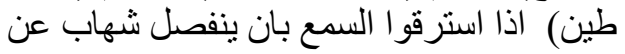

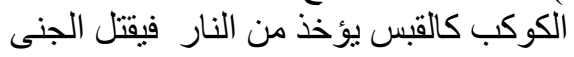

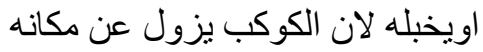

"(Dan sesungguhnya kami telah menghiasi langit yang dekat) yang dekat dengan bumi (dengan lampulampu) dengan bintang-bintang (dan kami jadikan bintang-bintang itu alat pelempar) alat untuk melempar dan merajam (setan-setan) bilamana

389 Indonesian Journal of Science and Mathematics Education ( I J S M E ) 
mereka mencuri pembicaraan para malaikat dengan telinga mereka; umpamanya terpisah batu meteor dari bintang-bintang itu yang bentuknya bagaikan gumpalan api, lalu mengejar setan dan membunuhnya atau membuatnya cacat. Pengertian ini bukan berarti bahwa bintang-bintang itu lenyap dari tempatnya."

Jika kita kaji lebih dalam lagi dalam penggunaan bahasa yang Allah gunakan pada ayat tersebut, ternyata terdapat keindahan di dalamnya. Ketika ayat tersebut menjelaskan mengenai asal usul meteor, Allah mengungkapkannya tidak menggunakan kata nujum (نجوم) ataupun kawakib (كواكب) yang sering diartikan sebagai bintan-bintang, akan tetapi Allah menggunakan kata masoobiih (مصابيح) yang berbentuk jamak.

Ketika kita tinjau dari segi bahasa arab, kata masoobiih ( مصابيح) merupakan jamak dari kalimat almisbah (المصباح) yang berarti pelita atau lampu atau sesuatu yang dijadikan penerangan dalam gelap, seperti halnya waktu subuh yang bersinar menyambut datangnya siang. Dengan demikian, ayat tersebut berarti telah memberi isyarat kepada kita bahwa benda-benda langit yang jatuh sebagai meteor itu berasal dari benda-benda langit yang nampak bercahaya saat kita lihat diwaktu malam, dan uniknya lagi, setelah muncul kajian sains, ternyata tidak semua benda langit yang tampak bercahaya saat kita lihat dimalam hari itu semuanya adalah bintang, dari kesemua benda yang bercahaya itu bisa berupa bintang, asteroid ataupun meteoroid yang memantulkan cahaya. Oleh karen itu, AlQur'an mengungkapkanya menggunakan kata masoobiih ( مصابيح) yang diartikan sebagai lampu-lampu bukan menggunakan kalimat nujum (نجوم) ataupun kawakib (كواكب) yang diartikan sebagai bintang. Inilah bukti bahwa AlQur'an selalu berlaku sepanjang zaman, Al-Qur'an selalu bersesuaian dengan kehidupan sepanjang zaman.

\section{Meteor Sebagai Penjaga Langit}

Meteor merupakan suatu istilah atau sebutan untuk penampakan jalur jatuhnya benda langit yang terbakar saat menembus atmosfer bumi, ketika benda luar angkasa tersebut tidak habis terbakar dan berhasil sampai ke bumi, maka sebutan benda tersebut bukanlah meteor lagi, melainkan benda tersebut disebut sebagai meteorit.

Terbakarnya benda langit tersebut terjadi akibat bergesekan dengan atmosfer bumi dengan kecepatan 25 kilometer per detik, sehingga menimbukan pijaran api yang sangat cemerlang. Pijaran api itu dapat dilihat dari bumi ketika meteor tersebut berada pada ketinggian 150 kilometer di atas permukaan bumi (Thayyarah 2013)

Ungkapan ini serupa dengan apa yang dikatakan dalam Al-Qur'an surat Ash-Saffat ayat 10.

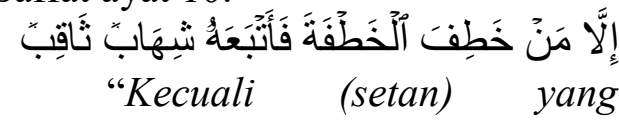

mencuri (pembicaraan), maka ia dikejar oleh meteor yang bersinar tajam."

Dalam ayat di atas, istilah meteor disebut sebagai syihab, yaitu suluh atau panah api yang bersinar tajam, seperti halnya penjelasan sains bahwa meteor akan menimbulkan pijaran api tatkala bergesekan dengan atmosfer bumi. di dalam tafsir jalalain juga dijelaskan:

$$
\begin{aligned}
& \text { الا من خطف الخطفة) مصدر اى الى }
\end{aligned}
$$

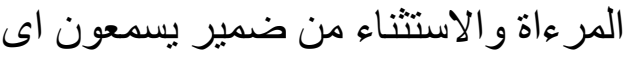

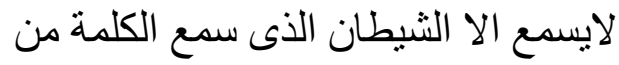

$$
\begin{aligned}
& \text { الملاعكة فاخذها بسر عة (فاتبعه شهاب) } \\
& \text { كوكب مضىء (ثاقب) يثقبه اويحرقها } \\
& \text { اويخبله }
\end{aligned}
$$

Terjemah tafsir:

(terkecuali setan yang mencuri-curi pembicaraan malaikat dengan sekali curi) lafadz Al-khotfatah adalah mashdar mararah dan yang diistisnakan adalah dzomir yang didalamnya terkandung lafadz laa yasma'una. Maksudnya tidak ada yang 
dapat mendengarkan pembicaraan para malaikat kecuali setan yang mencurinya dengan cepat (maka ia akan dikejar oleh syihab) yakni bintang yang bercahaya (yang melubanginya) yang menembus tubuh setan-setan itu, atau membakarnya, atau membuatnya cacat.(Jalaludin bin Muhammad Al-Mahali n.d.)

Dalam tafsir tersebut, kalimat syihaabun tsaaqibun dijelaskan sebagai bintang yang bersinar tajam yang dapat menembus tubuh setan, membakar atau membuat setan menjadi cacat. Tidak hanya itu, Syekh Jalaluddin bin Muhammad bin Ahmad Al-Mahali dan syekh Jalaluddin 'Abdurrahman bin Abi Bakrin Assuyuti dalam tafsirnya juga mengatakan, ayat di atas juga menjelaskan sebab terjadinya fenomena meteor tersebut, yakni karena setan yang mencuri dengar pembicaraan langit, maka ia akan dikejar oleh panah api yang bersinar tajam atau dalam istilah sainsnya disebut sebagai meteor. Dengan demikian, tanpa kita sadari ketika melihat fenomena meteor berarti kita sedang menyaksikan kebesaran Allah, dimana fenomena tersebut tidak terjadi begitu saja, melainkan para malaikat sedang melempari jin atau setan yang berusaha mencuri dengar pembicaraan langit.

Penjelasan ini juga diperkuat dengan ayat-ayat lain, diantaranya Q.S. Al-Jinn ayat 8-9, dan Q.S. Al-Hijr ayat 18

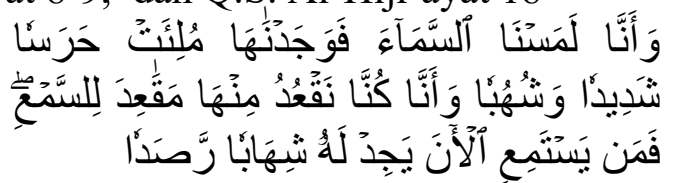

"Dan sesungguhnya kami (Jin) telah mencoba mengetahui (rahasia) langit, maka kami mandapatinya penuh dengan penjagaan yang kuat dan meteor-metor yang bersinar . dan sesungguhnya kami (Jin) dahulu dapat menduduki beberapa tempat di langit itu untuk mencuri dengar (beritaberitanya). Tetapi sekarang siapa (mencoba) mencuri dengan (seperti itu) pasti akan menjumpai meteormeteor yang mengintai (untuk membakarnya). (Al-Jin: 8-9).

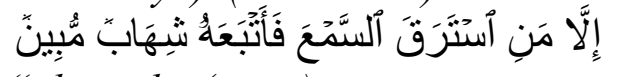

“..kecuali (setan)y yang mencuricuri (berita) yang dapat didengar (dari malaikat) lalu dikejar oleh meteor yang terang. Al-Hijr:18).

Nadiah Tharayyarah mengatakan dalam bukunya yang berjudul Buku pintar Sains dalam Al-Qur'an, bahwa meteor seperti terbuat dari batu-batuan dan besi yang dihaluskan, kemudian keduanya menjadi suatu kesatuan dan terbentuklah meteor. Hal ini menegaskan bahwa ada kekuatan magnetik di dalam meteor. Serpihan besi magnetik dari hancurnya suatu meteor itu akan menjadi dingin dan jatuh dari awan yang suhunya sangat panas kisaran lebih dari 5000 derajat celcius yang dimana awan itu berada di langat di atas wilayah yang dijatuhi meteor. Hal ini membuktikan bahwa meteor-meteor itu tertarik dengan sesuatu yang mengandung unsur api. Dengan demikian, hal ini semakin menguatkan pernyataan Al-Qur'an pada ayat di atas, bahwa meteor-meteor yang terjadi adalah sebagai alat pelempar jin. Karena pada dasarnya jin adalah mahluk Allah yang diciptakan dari api, (Thayyarah 2013). Sebagaimana firman Allah

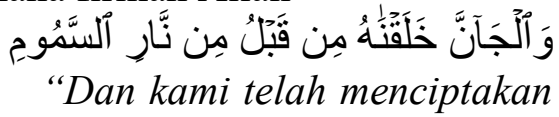
jin sebelum (Adam) daari api yang sangat panas."(QS. Al-Hijr:27).

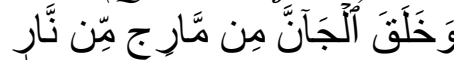

$$
\begin{aligned}
& \text { "Dan Dia (Allah) } \\
& \text { menciptakan jin dari nyala }
\end{aligned}
$$$$
\text { api."(QS. Ar-Rahman:15). }
$$

Dalam hadis juga dijelaskan, dalam hadits yang dikeluarkan oleh Imam Muslim, dari 'Aisyah, ia berkata, bahwa Rasulullah SAW bersabda:

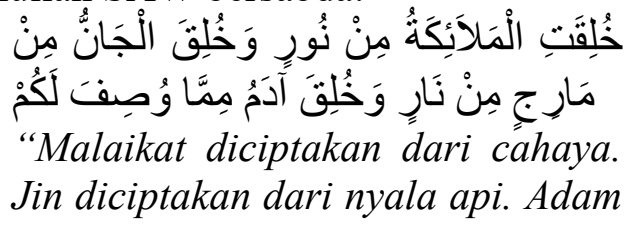

391 Indonesian Journal of Science and Mathematics Education ( I J S M E ) 


\section{diciptakan dari apa yang telah ada pada kalian."(HR. Muslim no.2996).}

\section{Meteor Sebagai Penghantar Air Ke Bumi}

Para ilmuwan telah memprekirakan bahwa bumi dijatuhi bahan meteor kisaran 150 juta meteor dalam setiap harinya(Thayyarah 2013). Ada beberapa meteor yang biasanya dapat disaksikan pada malam-malam tertentu.Bahkan terkadang jumlahnya meningkat secara dramatis, atau yang sering disebut sebagai peristiwa hujan meteor. Seperti halnya hujan meteor leonid yang terjadi pada 1718 November 2018.

Fenomena hujan meteor ini ada hubungannya dengan komet. Beberapa para ilmuan mengatakan bahwa fenomena hujan meteor terjadi ketika bumi melintasi orbit komet dan melalui lintasannya. Jauh sejak kurang lebih 35 miliar tahun lalu, planet bumi mengalami benturan bertubitubi dengan ribuan meteor berasal dari komet yang mengandung kristal-kristal es. Peristiwa ini berlangsung sejak meliaran tahun lalu dan berlanjut hingga saat ini(Sudarmojo 2013).

Peristiwa benda langit juga telah dijelaskan dalam Al-Qur'an pada surat At-Tariq (الطارق) yang dalam mushaf AlQur'an merupakan surat ke 86, tediri 17 ayat dan diwahyukan di Makkah pada tahun ke-8 kenabian atau pada tahun 618 M, sesudah surat Qaf dan surat Al-Balad. Surat ini turun ketika Abu Tholib mendatangi Rasulullah dengan membawa roti dan susu. Setelah Abu Thalib duduk, terlihat sebuah bintang jatuh sehingga daerah sekitarnya seakan dipenuhi api karena sangat terangnya cahaya bintang tersebut. Abu Thalib pun bertanya kepada Rasulullah, "Apa ini?" lantas Rasulullah pun menjawab, "ini adalah bintang yang dilemparkan dan merupakan satu dari sekian banyak tanda-tanda kekuasaan Allah."

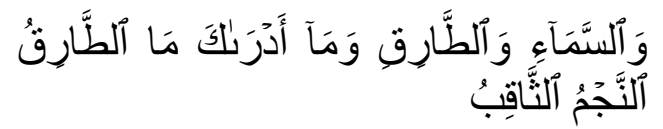

"Demi langit yang datang pada malam hari. Dan tahukah kamu apa yang datang pada malam hari itu?

Yaitu bintang yang bersinar tajam."

Surat ini diawali dengan kalimat wassamaai wattaariq (و والطارقو السماء) ). Dalam ayat ini Allah bersumpah dengan langit dan suatu benda langit yang disebut Attaariq (الطارق). Istilah At-taariq (الطارق)

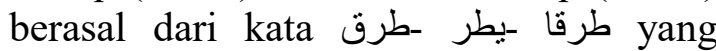
dalam bahasa arab sehari-hari At-taariq digunakan sebagai istilah untuk menyebut tamu yang jarang datang dan tiba-tiba datang pada malam hari (Yunus 1972) Dengan demikian jelaslah bahwa At-taariq dalam ayat ini adalah benda langit yang langka kehadirannya. Tidak setiap malam kita dapat menyaksikannya, karena benda ini datang sewaktu-waktu atau secara periodik(ITB 2014).

Kemudian pada ayat berikutnya digunakan kalimat wama adraaka maa attoriq (وماادرالك ماالطارق). Jika kita lihat dalam Al-Qur'an, satu-satunya benda langit yang menggunakan kalimat wama adraaka (وماد) ( (الطارق), hal ini semakin memperkuat penalaran kita, bahwa At-taariq (الطارق) adalah benda langit yang tidak biasa dan jarang datang, yaitu komet yang muncul sekali dalam beberapa tahun atau bahkan ratusan tahun. Benda-benda langit yang lain seperti matahari, bulan dan pelanet tidak pernah diterangkan menggunakan kalimat wama adraaka sebab istilahistilah itu sudah jelas maknanya dan benda-bendanya dapat kita saksikan setiap waktu. Identifikasi benda langit At-taariq (الطارق) yang diartikan sebagai komet telah ditunjang oleh data astronomi, ketika surat at-taariq diwahyukan Allah kepada nabi Muhammad SAW pada tahun ke-8 kenabian atau pada tahun $618 \mathrm{M}$. Pada tahun itu muncul komet besar yang termasyhur dalam sejarah. Yaitu apa yang sekarang kita namakan sebagai komet Halley. Periode kedatangan komet ini, 
pertama kali diteliti oleh ilmuan astronomi Inggris bernama Edmond Halley, ia mengetahui bahwa komet yang muncul pada tahun 1531,1607 , dan 1682 adalah benda yang sama, yaitu komet Halley.

Pada ayat ketiga, kalimat an-najmu tsaaqib. Jika diartikan secara harfiah berarti benda-benda langit yang melubangi. Informasi awal ayat ke-3 dalam surat At-taariq ini semakin memperkuat penafsiran bahwa yang dimaksud At-taariq (الطارق) ini adalah komet. Sebagaimana yang dipelajari dalam ilmu astronomi, komet adalah benda langit yang diameternya mencapai puluhan kilometer, tersusun dari kandungan es kotor. Yaitu terdiri dari molekul air $\left(\mathrm{H}_{2} \mathrm{O}\right)$, amonia $\left(\mathrm{NH}_{3}\right)$, karbondioksida $\left(\mathrm{CO}_{2}\right)$ metana $\left(\mathrm{CH}_{4}\right)$ yang didalamnya bercampur debu. Sebagian zat itu terhambur menjadi debu dan gas yang berbentuk ekor pada saat mengorbit dekat matahari.

Dalam proses pembentukan tata surya, komet-komet membombardir pelanet-pelanet bertanah, dan menimbulkan lubangan-lubangan pada planet tersebut. Salah satu dianataranya adalah pelanet bumi. Komet tersebut datang untuk menymbangkan air yang merupkan syarat mutlak kehidupan. Dan dari proses serbuan komet itulah lautan tak bertepi terbentuk di bumi(ITB 2014).

Terbentuknya lautan dibumi, telah menjadi misteri selama bertahun-tahun. Seorang ilmuan William Walden Rubey pada tahun 1951 pernah mencatat dan melakukan perhitungan cadangan air di bumi. Ia merasa kebingungan dengan adanya jumlah air yang sangat luar biasa, yang mana air itu tidak diketahui darimana asalanya. Hingga pada tahun 1986 seorang ahli fisika dari lowa Amerika serikat Dr. Louis A. Frank dan J.B. sigwart, mempertaruhkan karir akademisnya dengan mengatakan bahwa melalui data-data penelitiannya dari Viking Spaceraft. Bahwa pesawat ruangkasa ini telah memotret planet bumi dengan menggunakan film ultraviolet. Dan foto-foto itu menunjukan bahwa atmosfer bumi tampak berlubang dimanamana. Hal ini menunjukan bahwa lubanglubang itu merupakan jejak serbuan dari ribuan komet yang membawa air. Meskipun penelitian ini sempat dibantah oleh para peniliti lain, namun pada akhrinya tigabelas tahun kemudian penelitian ini telah diakui setelah melewati forum perdebatan sains yang cukup ketat(Sudarmojo 2013).

Fenomena komet pembawa kristal es juga telah Allah jelaskan pada surat Annur ayat 43 yang diwahyukan pada nabi Muhammad SAW sejak 7 abad silam.

"Tidaklah kamu melihat bahwa Allah mengarak awan, Kemudian mengumpulkan antara (bagianbagian)nya, Kemudian menjadikannya bertindih-tindih, Maka kelihatanlah olehmu hujan keluar dari celahcelahnya dan Allah (juga) menurunkan (butiran-butiran) es dari langit, (yaitu) dari (gumpalan-gumpalan awan seperti) gunung-gunung, Maka ditimpakan-Nya (butiran-butiran) es itu kepada siapa yang dikehendaki-Nya dan dipalingkan-Nya dari siapa yang dikehendaki-Nya. Kilauan kilat awan itu hampir-hampir menghilangkan penglihatan. (Q.S. An-Nur:43).”

Ketika kita melihat data-data sains dan hubungannya dengan ayat tersebut barulah kita dapat memahami makna firman Allah, bahwa Allah menurunkan butiran-butiran es dari langit, yaitu gumpalan-gumpalan es seperti gununggunung. Ternyta butiran-butiran es yang dibawa komet-komet laksana gunung dan membentur atmosfer bumi secara teru menerus(Sudarmojo 2013).

Berdasarkan penelitian, dikatakan bahwa spektrum-spektrum yang dipancarkan oleh komet Halley dan komet lainya tenyata menunjukan bahwa isotop hidrogen dan deuterium pada $\mathrm{H}_{2} \mathrm{O}$ air laut ternyata sama persis dengan $\mathrm{H}_{2} \mathrm{O}$ yang

393 Indonesian Journal of Science and Mathematics Education ( I J S M E ) 
terdapat pada komet-komet. Fakta ini membuktikan bahwa bumi tidak dapat memproduksi air sendiri, melainkan air yang ada di bumi adalah air dari meteormeteor yang berasal dari komet(ITB 2014).

Pada ayat di atas dikatakan bahwasannya Allah telah menjadikan air menetap di bumi, dan Allah berkuasa untuk menghilangkannya. Sungguh Mahabesar Allah. Kebenaran makna ayat ini membuat kita semakin tertegun dan kagum. Memang Allah lah yang berkuasa melenyapkannya. Karena dari beberapa planet yang mendapati serbuan kometkomet pada saat proses pembentukan tata surya dahulu, bumilah satu-satunya planet yang bisa menampung air. Lain halnya planet lain yang tidak bisa menampung air, seperti planet Mars misalnya, yang mana para ahli geologi planet Mars bersama ahli astrologi dan kosmologi yang tergabung dalam NASA telah menemukan jejak-jejak air di planet Mars, akan tetapi kini tidak ada lagi dikarenakan gaya gravitasi planet mars sangatlah kecil sehingga tidak dapat mempertahankan air.

\section{Meteor Sebagai Pengantar Besi Ke Bumi}

Sesungguhnya kami Telah mengutus rasul-rasul kami dengan membawa bukti-bukti yang nyata dan Telah kami turunkan bersama mereka Al Kitab dan neraca (keadilan) supaya manusia dapat melaksanakan keadilan. dan kami ciptakan besi yang padanya terdapat kekuatan yang hebat dan berbagai manfaat bagi manusia, (supaya mereka mempergunakan besi itu) dan supaya Allah mengetahui siapa yang menolong (agama)Nya dan rasul-rasul-Nya padahal Allah tidak dilihatnya. Sesungguhnya Allah Maha Kuat lagi Maha Perkasa.(Q.S. Alhadid:25).

Ungkapan Al-Qur'an bahwa besi diturunkan dari langit membuat para ilmuan mendalami bagaimana terbentuknya besi di dunia ini. Pada mulanya para ahli astronomi beranggapan bahwa besi merupakan unsur biasa yang terbentuk dalam proses geologi di bumi. Namun, berdasarkan kajian mutakhir Profesor Armstrong atau Mohamed Asadi salah seorang ilmuan NASA (National Aeronautics and Space Administration) USA, ia memiliki pandangan yang berbeda. Ia memnganggap bahwa besi merupakan logam yang unik. Diperlukan sebuah tenaga yang sangat tinggi, melebihi tenaga yang ada dalam sistem matahari untuk dapat membentuk suatu unsur besi (Sampayya 2007).

Penemuan astronomi modern saat ini mengatakan bahwa bumi tidak dapat memproduksi logam besi sendiri, melainkan logam besi dapat terbentuk melalui reaksi fusi pada inti bintangbintang berukuran raksasa yang massanya lebih dari 10 kali massa matahari (Pratama 2018).

Berdasarkan bantuan teleskopteleskop raksasa, para ilmuan dapat mengetahui bahwa dalam setiap jamnya terdapat bintang-bintang yang telah mati.Namun, sebelum bintang-bintang itu mati, ada fenomena menarik yang terjadi. Yaitu dimana bintang itu tiba-tiba bersinar sangat terang hingga ratusan ribu kali terangnya matahari, dan ukurannya pun ikut membesar hingga ribuan kilometer per detik, lantas meledak dangan ledakan yang sangat dahsyat (Thayyarah 2013).

Dalam proses kehidupanya, bintang dapat terjadi masa redup dan masa terang. Salah satu penyebab bintang dapat menyala adalah terjadinya proses fusi nuklir didalam tubuh bintang sehingga terbentuklah besi di dalam inti bintang. Ketika proses ini telah berhenti dan tidak dapat memproduksi besi lagi, maka bintang itu akan meledak dan pecahaanpecahan bintang tersebut akan terpencar kesegala arah dan masuk dalam ruanganruangan grafitasi benda-benda langit termasuk bumi Jika kita amati, hal ini 
sama dengan jatuhnya meteor-meteor kebumi.

Ungkapan bahwa besi diturunkan dari langit semakin kuat dengan adanya penemuan bahwa unsur-unsur meteor yang jatuh ke bumi, ternyata terdapat kesamaan dengan materi kimia yang ada di bumi. Yaitu dimana meteor-meteor tersebut seperti terbuat dari batuanbatuan dan besi yang dihaluskan. Menurut emeritus, meteor terbagi menjadi tiga bagian, yaitu meteor besi dimana meteor ini 98\% mengandung besi dan nikel, meteor besi-batu meteor ini sebagian muatannya mengandung besi dan nikel dan setengahnya lagi bermuatan batu, dan meteor batu yaitu meteor yang hanya bermuatan batu (Thayyarah 2013).

\section{Meteor Sebagai Bencana Bagi Mahluk Di Bumi}

Selama berabad-abad, kisah legenda bahwa bumi telah mengalami bencana global akibat hantaman benda luar angkasa masih sulit dipercaya. Laporanlaporan mengenai adanya batu yang jatuh dari langit hanya dipandang sebelah mata. Mereka menganggap laporan semacam itu hanyalah dongeng belaka. Hingga pada akhirnya Jean Biot seorang ahli astronomi yang melakukan penelitianya saat 26 April 1803 ketika desa L'Aigle Nomrmandia dihujani ribuan meteoroit. Ia mengatakan, bahwa berdasarkan penelitiannya, batu-batu meteoroit tersebut memang berasal dari langit.

Hingga pada tahun 1980 tim ilmuwan University of california at Berkeley di bawah pimpinan seorang ahli fisika Amerika sekaligus pemenang Hadiah Nobel Luis Alvarez. Mereka berhasil mengungkap mesteri uniformitarianisme yang selama 150 tahun terpenjarakan. Berdasarkan penelitiannya terhadap catatan fosil kepunahan dinosaurus, mereka mendapati sampel tanah liat di sekitaran peristiwa itu mengandung iridium yang sangat tinggi, yang mana unsur tersebut relatif lazim ditemukan pada meteor. Ditemukannya iridium tinggi ini sungguh mengherankan, karena daripadanya terdapat suatu tanda yang menunjukan adanya tabrakan meteor raksasa yang ukuran garis tengahnya berkisar $5-10 \mathrm{~km}$. Berdasarkan penelitian, tabrakan semacam itulah yang memicu kebakaran besar global, yang mana asap dan abunya menghalangi sinar matahari sampai ke bumi, sehingga rantai-rantai makanan di bumi pun lenyap. Hal inilah yang menyebabkan lenyapnya kekuasaan dinosaurus di bumi(Matthews 2015).

Berdasarkan sejarah bahwa bumi telah mengalami bencana global yang dahsyat akibat hantaman meteor itulah, para ilmuwan saat ini mulai menyadari akan adanya ancaman dari langit. Dan mereka pun mulai membentuk sejumlah proyek utnuk menghadapi ancaman dari meteor-meteor yang berpotensi mengancam bumi. Salah satunya yaitu proyek NEO (Near-EarthObyect). Proyek tersebut memiliki misi untuk meneliti dan mendeteksi obyek-obyek benda luar angkasa yang berpotensi menabrak bumi. Metoroit, komet, ataupun benda langit lainnya yang memiliki diameter minimum $1 \mathrm{~km}$ dan gerak orbitnya mendekati bumi maka benda ini disebut sebagai NEO(Dedi n.d.).

Mengenai adanya ancaman dari langit Allah juga telah menjelaskannya di dalam Al-Qur'an surat Al-Mulk ayat 16 yang dalam tafsir Jalalin dijelaskan:

"(Apakah kalian merasa aman) dapat dibaca secara tahqiq dan dapat pula dibaca secara tashil (terhadap kekuasaan Allah yang di langit) yakni pengaruh dan kekuasaan-Nya yang di langit (bahwa Dia akan menjungkir balikan) berkedudukan menjadi badal lafadz man (bumi bersama kalian, sehingga dengan tiba-tiba bumi itu terguncang) menjadi gempa dan menindih kalian)".9Q.S. Al-Mulk ayat 16).

Dengan melihat keterangan tafsir di atas, maka membuat kita berasumsi

395 Indonesian Journal of Science and Mathematics Education ( I J S M E ) 
bahwa yang dimaksud dengan berguncangnya bumi akibat ancaman dari langit adalah akibat hantaman meteor. Karena satu-satunya objek dari langit yang membahayakan bumi adalah meteor. Dan sungguh mengherankan lagi, pada tanggal 31 Januari 2009, seorang astronom Robert Hokmes dari Astronomical Research Institut telah menemukan asteroid ynag berpotensi mengancam bumi atau PHA (potentially hazardous asteroid). Sekitar 250 asteroid, 6 supernova, dan 1 komet telah ditemukan oleh Holmes. Hal ini semakin membuktikan akan kebenaran Al-Qur'an.

\section{B. Upaya Yang Harus Dilakukan Dalam Menghadapi Bencana Meteor Berdasarkan Kajian AL-Qur'an Dan Sains}

Sebagaimana penjelesan di atas, bahwa jika meteor berukuran raksasa berhasil menbrak bumi, maka dampak yang ditimbulkan meteor sangatlah besar, berupa energi bom atom yang sangat kuat sehingga memunculkan debu-debu ledakan atau kabut asap yang panas (dukhaan) yang beterbangan ke atmosfer bumi dan menutupi sinar matahari untuk sampai ke bumi. Ketika sinar matahari (ultraviolet/UV) yang berfungsi membunuh bakteri dan virus serta berperan penting dalam pem akan terhalang masuk keatmosfer bumi, maka bakteri dan virus yang ada di bumi akan hidup dan berkembang subur serta sistem imun manusia akan menurun. Sehingga bakteri dan virus tersebut akan mudah menyerang manusia.

Adanya keyakinan bahwa bencana dahsyat akibat meteor suatu saat benarbenar akan terjadi, saat ini beberapa negara-negara maju mereka ketakutan kalau hal itu benar-benar akan terjadi, sehingga mereka sibuk mempersiapakn untuk menghadapi hal tersebut. Salah satu upaya mereka adalah dengan dibuatnya gedung anti kiamat. Seperti halnya gedung anti kiamat buatan Australia yang dibangun di New South Wales dan juga di Kansas Amerika Serikat dengan kedalam 53 meter. Mereka meyakini bahwa gedung tersebut bisa menyelamatkan mereka dari semua bencana yang terjadi saat hari kiamat(Sasongko 2008).

Namun berbeda dengan orang-orang muslim yang mukmin, upaya mereka dalam menghadapi peristiwa tersebut tidak hanya dengan persiapan meteri saja. Akan tetapi mereka mempersiapkan dengan amal shaleh salah satunya seperti puasa. Sebagaimana yang dikatakan nabi saw. bahwa puasa adalah perisai bagi orang-orang muslim yang menjalankannya, baik di dunia maupun di akhirat (Ridho al-Thurisinai; Buka Puasa Bersama Rasulullah Saw).

Berdasarkan kajian sains juga dikatan bahwa puasa merupakan perisai, karena dengan puasa seseorang tersebut akan sehat fisik maupun psikisnya. Sebagaimana yang telah dikatakan oleh Prof. Dr. dr. H. Dadang Hawari, Psi, bahwa para pakar mengatakan,bentuk perisai yang dihasilkan dari puasa adalah bertambahnya sel darah putih dan diblokirnya suplay makanan untuk bakteri, virus dan sel kanker. Sehingga system kekebalan tubuh orang yang menjalani puasa akan meningkat, dan tidak mudah terserang penyakit(Sasongko 2008)

\section{KESIMPULAN}

1. Meteor dalam sains merupakan subuah istilah penampakan jalur jatuhnya benda langit ke bumi sedangkan dalam istilah Al-Qur'an disebut sebagai syihab.

2. Sains mengatakan bahwa tidak dapat diketahui entah dari mana meteor berasal, bisa jadi berasal dari asteroid, komet, ataupun benda langit lainnya. Sebagaimana yang dikatakan dalam Al-qur'an surat Al-Mulk ayat 5. 
3. Substansinya meteor merupakan tentara Allah yang bertugas sebagai penjaga langit yang mencuri dengar berita langit, sebagaimana firman-Nya dalam Q.S. Ash-Saffat ayat 10, Al-Hijr ayat 18, Al-Jinn ayat 8-9, Al-mulk ayat 5. Yang dalam baru-baru ini sains telah berhasil membuktikannya melalui pernyataan bahwa Serpihan besi magnetik dari hancurnya suatu meteor itu akan menjadi dingin dan jatuh dari awan yang suhunya sangat panas kisaran lebih dari 5000 derajat celcius yang dimana awan itu berada di langat di atas wilayah yang dijatuhi meteor. Hal ini membuktikan bahwa meteormeteor itu tertarik dengan sesuatu yang mengandung unsur api, dan Jin merupakan mahluk yang terbuat dari api.

4. Meteor merupakan sebagai penghantar air ke bumi, seperti halnya yang dikatakan sains bahwa pada proses pembentukan tata surya bumi telah dibombardir ribuanmeteor yang berasal dari komet yang mengandung air. Hal ini sebagaimana yang dijelaskan dalam Al-Qur'an suratAt-taariq ayat 1-3.

5. Meteor merupakan sebagai penghantar besi ke bumi, sebagaimana penjelasan sains bahwa bumi tidak dapat memproduksi besi sendiri, melainkan logam besi dapat terbentuk melalui reaksi fusi pada inti bintang-bintang berukuran raksasa yang massanya lebih dari 10 kali massa matahari. Hal ini sebagaiman yang dijelaskan dalam Al-qur'an surat Al-hadid ayat 25 yang mengatakan bahwa besi turun dari langit.

6. Meteor merupakan sebagai ancaman bencana bagi berlangsungnya kehidupan manusia di bumi. Sebagaimana yang dikatakan dalam Al-Qur'an Al-Mulk ayat 16, dan penjelasan sains bahwa suatu saat bumi akan mengalami bencana global sebagaimana bencana yang dialami mahluk bumi dinosaurus pada 65 juta tahun lalu.

Berdasarkan kajian sains dan AlQur'an bahwa bencana yang disebabkan jatunya meteor sangatlah dahsyat, langit bumi akan menjadi gelap akibat tertutup oleh kabut asap yang tebal, maka upaya yang harus dilakukan dalam menghadapi bencana tersebut ialah dengan berpuasa. Karena berdasarkan kajian islam dan sains dikatakan bahwa puasa merupak perisai baik di dunia maupun di akhirat. Dengan berpuasa maka sistem kekebalan tubuh akan meningkata akibat bertambahnya sel darah putih

\section{DAFTAR PUSTAKA}

Deded Chandra, M. nasir, Zawirman. 2016. "Dasar-Dasar Astronomi."

Dedi. Ancaman Asteroid Di Depan Mata, Bumi Terancam Hancur Berdasarkan Fakta Ilmiah,. Jakarta: Titik Media Pubilisher.

Iskandar. 2013. Metodologi Penelitian Pendidikandan Sosial. Jakarta: Referensi.

ITB, Tim tafsir Ilmiah Salman. 2014. Tafsir Salman: Tafsir Ilmiah Juz 'Amma. Bandung: Mizan Pustaka.

Jalaludin bin Muhammad Al-Mahali, Syaikh Jalaludin 'bdurohman bin abi Bakrin Assuyuti. Tafsir Jalalin. daru ihyailkitab.

Kaelan. 2012. Metode Penelitian Kualitatif Interdisipliner. Yogyakarta: Paradigma.

Matthews, Robert. 2015. "25 Gagasan Besar Sains Yang Mengubah Dunia Kita."

Pratama, Eka. 2018. Perjalanan Mencari Kebenaran. Sukabumi: CV Jejak.

Sampayya, Abah Salma Alif. 2007. Keseimbangan Matematika Dalam Al-Qur'an. Jakarta: Republika.

Sasongko, Wisnu. 2008. "Armagedon 2 Antara Petaka Dan Rahmat.": 42.

Sudarmojo, Agus Haryo. 2013. History of Eart Menyingkap Keajaiban Bumi Dalam Al-Qur'an. Yogyakarta:

397 Indonesian Journal of Science and Mathematics Education ( I J S M E ) 
MIzan.

Sugiyono. 2016. Metode Penelitian Kuantitatif, Kualitatif Dan R\&D. 1st ed. bandung: alfabeta.

Thayyarah, Nadiah. 2013. Buku Pintar Sains Dalam Al-Qur'an. Jakarta: Zaman.

Yuberti, Widayanti. 2018. "Pengembangan Alat Praktikum Sederhana Sebagai Media Praktikum Mahasiswa." 2(1): 21-27.

Yunus, Mahmud. 1972. Kamus Arab Indonesia. 1st ed. jakarta: yayasan Penyelenggara penterjemah/pentashih Al-Qur'an.

Zed, Mestika. 2017. Metode Penelitian Kepustakaan. Jakarta: Yayasan Pustaka Obor Indonesia. 